\title{
Industrial relations transformation in the framework of European Union standards: the case of Bulgaria
}

\begin{abstract}
This article reviews the impact of European Union long-term strategies on industrial relations standards at both international and national levels - the latter with a particular focus on Bulgaria. Such strategies have the aim of enabling the European economy better to compete on the international stage, but they also present direct challenges to the labour market and to the industrial relations institutions at a time when these are already under severe pressure as a result of the global financial and economic crisis. The author discusses several issues which are problematic in the extension of EU-wide strategies to Bulgaria, particularly as regards their impact on the labour market, with the latter also undergoing transformation in the process of recovery and adaptation to European-style structures and approaches. The article concludes that there needs to be better integration between European and national level systems if long-term strategies are to have a chance, but that resistance and fear may act as an effective block on the potential success of trans-nationalisation.
\end{abstract}

Keywords: EU, labour market, globalisation, low carbon economy, social cohesion, skills, flexibility, migration, social dialogue, industrial relations, information and consultation, lifelong learning, restructuring, CSR, social dumping, investment

Introduction

The Europe 2020 strategy seems to present a new challenge for European Union (EU) member states, as well as the chance for many of them to improve their economies, labour market, education, sciences and technologies, and environmental protection. The implementation of the Lisbon Strategy, which was passed in 2000, was not sufficiently successful for all EU member states; and its results have been weakened as a result of the world financial crisis, which had started in 2008. However, there are expectations that a new strategy, with new steps and new approaches, could lead to better results.

Both the Lisbon Strategy and the new Europe 2020 strategy were set up to address the remaining long-term challenges which all European societies are now facing: globalisation; the transition towards a low carbon economy; aging populations; and strengthening towards a more socially cohesive society, based on equal opportunities and equal treatment. ${ }^{1}$

1 ETUC, BUSINESS EUROPE, CEEP, UEAPME (2010) Joint Statement on Europe 2020 Strategy 4 June, p. 1. 
Some of the main indicators of the Strategy were related to growth (a $3 \%$ average over a decade); the percentage of GDP invested in R\&D (3\%); the overall employment rate $(70 \%)$; and to particular employment rates for women $(60 \%)$ and for workers aged $55-64(50 \%)$.

However, in 2005 the mid-term review of the implementation of the strategy presented the modest progress which had been achieved, and the European Commission (EC) took the recommendation that the Strategy should focus on two main indicators, such as jobs and growth, and that the objectives of these two main dimensions - at national and European level - should be better clarified. In many countries, progress was reached during the following five years (2006-2010), but the beginning of the world financial crisis brought to a stop both economic growth and the increase of employment in many EU-member states. For some of them, financial problems also appeared.

At the same time, the Lisbon Strategy was not legally binding and individual countries could not be forced to achieve the purposes of the Strategy. For some of them, especially most of the new EU member states, it is extremely difficult to reach a balance between economic growth, the renewal of technology and implementing all the principles of the European social model and social cohesion.

The progress that has been achieved in regard to the employment rate in most countries in the last decade has been exclusively attributable to atypical contracts. ${ }^{2}$ In 2010 , there was a growth in temporary employment - the total hours worked in the context of temporary jobs was about $23 \%$ in October 2010. There is also more parttime work.

The Europe 2020 strategy seems to be more clear and particular, but it is also based on several different pillars. The main purpose of Europe 2020 is the establishment of conditions for the better competition of the EU-economy with other economic giants, but it challenges once again the European social model and European industrial relations systems, as well as national social models and national systems of industrial relations within the member states. At the same time, social models and industrial relations have already been challenged by the world financial and economic crisis, whose consequences have still not been overcome.

Some of the purposes and indicators within the new strategy seem to be very similar to the requirements of the old Lisbon Strategy, but the new strategy is more focused on energy saving and renewable energy resources, as well as on the improvement of education, including primary and secondary education as a prerequisite for employment growth and the reduction of poverty.

Immediately after the acceptance of the new Strategy, some criticisms addressed to it, and expressed by politicians and researchers, began to appear. The politicians intend mainly to criticise the balance between national and European dimensions; while researchers try to review more broadly the contents of the strategy and the quality of its aims. According to Philippe Pochet, the General Director of the European Trade Union Institute, there could be many questions stated and many problems defined within the new Strategy, including as follows:

2 Pochet, Philippe (2010) 'What is wrong with Europe 2020?' ETUI Policy brief on social policy No. 2. 2010, pp. 3-6. 
- there could be difficulties in reaching a balance in the context of restricting the consequences of both the economic and financial crisis and the environmental crisis

- the questions of labour market fragmentation, wage inequalities and the quality of work have not been raised by the Strategy; and lessons from the Lisbon Strategy have not been learned

- inequalities are limited to questions of health and poverty

- there are tremendous differences in the results of member states - one example is post-secondary education. ${ }^{3}$

The implementation of the new Strategy could be improved by a single market act of the European Commission, with processes under the existing one brought to an end in April 2011, and a second Act, the final version of which is under preparation as of October 2012. The first one foresaw new policies in several main areas, including: better access to capital, especially for small and micro enterprises; analysis of the social impact of single market legislation; the improvement of the directive on professional qualifications; the promotion of social economics and of innovative social enterprises; the resolution of conflicts; the promotion of new technologies; etc. The second act also includes some agents of growth, such as the establishment of integrative networks in the framework of the single market, the promotion of the mobility of citizens and enterprises, support for the digital economy and the promotion of social entrepreneurship, cohesion and the trust of consumers. Some of the new policies correspond to Europe 2020 objectives, especially those regarding the green economy, the growth of the employment rate and the reduction of poverty.

However, the two single market acts are mainly focused on the markets of goods, capital and services, and not as much on the labour market. Attention is paid to the social consequences and to social cohesion, but the role of human resources in facilitating growth and competitiveness has not been properly examined.

At the same time, the implementation of the new Europe 2020 strategy could bring innovations in economics, in labour and social policy and in industrial relations at both the national and the European levels, which may improve the quality of life of European citizens.

\section{European industrial relations in the perspective of the Europe 2020 strategy}

The transformation of labour in the perspective of Europe 2020-European dimensions

It is certain that Europe 2020 presents a new challenge to the continued transformation of labour which has already been caused by globalisation. There are seven flagship initiatives in Europe 2020: an innovation union; youth on the move; a digital agenda for Europe; a resource-efficient Europe; an industrial policy for the globalisation era; an agenda for new skills and jobs; a European platform to tackle poverty. Most of these could provoke changes in industrial policies, as a result of current and further restructuring. They could also lead to the appearance of new jobs, companies and sectors as well as to decline and the disappearance of many others. At the same time, new

\section{3 ibid.}


employment and a new workforce could appear and, probably, new labour standards established, too.

The decline of those industries which are still using old energy resources or old technologies, provoking environmental problems, or old agricultural methods, is possible. In any case, the reduction of employment in some sectors and companies is both possible and also happening now. The increase in employment at national or European level in the short-term, or over a longer period of time, may slow down or, at least, the creation of mainly atypical new jobs could result.

Some conclusions from research studies show that 'green' investment, especially in renewable energy sectors and environmental construction, is a potentially significant engine for job creation. The result depends on policies surrounding the promotion of the new skills required by these new industries. Some analyses, based on research into the practices of 'green' restructuring and training policies, give the conclusion that the new skills could be established even when they are based on existing competences, but especially so when new approaches to qualifications are used. ${ }^{4}$

Some other conditions could also influence changes in the labour market, among them being these six:

- the challenge resulting from the new objectives of world-wide competition, which are not equal for all countries. Not all EU member states have the abilities to reach these: they either still have not been able to define their competitive advantage, or have not been able to use this in an appropriate way

- the challenge presented by the still-strong influence of the crisis - in fact, there are new steps in the crisis, the most recent one of which is appearing mainly as a severe recession in some countries but also as financial collapse in several others. The consequences of the crisis are barriers to the transformation of the economy and to the increase of employment. Between 2008 and 2010, the crisis brought a reduction or the 'freezing' of wages and salaries in the public sector, as well as the implementation of more passive wages policies, the reduction of productivity and labour market segmentation; in 2011-2012, it is causing also an increase in inequalities which can be observed on the labour market and in the conditions of labour and the living standards of the population ${ }^{5}$

- the will for the establishment of a common EU model of financing and tax policy, bearing in mind the new 'Euro plus' pact on the co-ordination of national economies and the improvement of financial stability

- growing scepticism towards the European Union in some countries, which could make more difficult the implementation of national targets in the new Strategy. Such trends have already been expressed by some government leaders of EU member states. Such scepticism has been rapidly increased by the crisis

4 European Centre for the Development of Vocational Training (2010) Skills for green jobs: European synthesis report in conjunction with the International Labour Office, Luxemburg: Publications Office of the European Union, pp. 3-4.

5 ETUI (2012) Benchmarking Working Europe ETUI: Brussels. 
- demographic issues, especially the aging of population, which could make the innovation process too difficult and which could also put a halt to the increase in employment and make the reduction of poverty more complicated

- the extension of the common labour market and the increase of migration inside the EU, and also of immigration from outside, presents major challenges to labour standards and to social security.

Some of these challenges could be barriers which are too tough for many EU member states in the implementation of the Europe 2020 strategy. In many cases, they may not be able to be overcome. It has been said that:

The Achilles heel of Europe is its people,

including as regards the aging of population, the shrinking labour force and the inability to attract a skilled foreign workforce. Highly-skilled foreign workers account for only $1.7 \%$ of all workers in the EU, compared to $9.9 \%$ in Australia, $7.3 \%$ in Canada and $3.5 \%$ in the United States. A massive $85 \%$ of unskilled foreign labour comes to the EU, while only $5 \%$ goes to the US. Europe may already be a home for $42 \%$ of migration across the globe, but it has succeeded in attracting mainly low-skilled and unskilled people. ${ }^{6}$

The result is that the aging of the population has progressed, the new labour force (mainly immigrants) is low-skilled and their integration into European societies, including in education systems, has been too difficult. This questions the objectives as regards the improvement of education and training, innovation in industries and in technologies, including the implementation of more green technologies, and also in the growth of employment and the reduction of poverty. For reaching its new objectives even in part, EU member states need radically to change their approaches and mechanisms for policy implementation, and even to change the attitudes of their populations and societies.

\section{Industrial relations in the European Union under the transformation of labour}

The new labour and the new workforce, which would emerge in the case of the success of the new Europe 2020 strategy, could have an impact on industrial relations and the social dialogue. Firstly, the changes in industries, companies, labour and the workforce could generate new approaches in company and sector-level industrial relations since the actors will also change. Secondly, new policies will also require new views among the social partners concerning energy resources, environmental protection and climate change, and sustainable development as a whole, as well as the education and training of the workforce and new work ethics.

Industrial relations in most EU member states are still based on the pillars of post-1945 western Europe - trade unions and employer organisations as the main actors; the co-ordination of collective bargaining; employee representation in firms; and consultation between the social partners on social and economic issues on a regular

6 'EU at risk if Europe 2020 fails to deliver' 9 February 2011 www.euroactiv.com. 
basis. $^{7}$ The same pillars are also taken into account in post-communist countries, but the process has taken too long as a result of the hard transition of national economies.

At European level, there is also a social dialogue and first steps in the Europeanisation of industrial relations but, for a long time, the common decisions at the level of the EU as a whole regarding labour and social issues could only have been taken by consensus. After the mid 1980s, the limited capacity of Community influence on industrial relations was extended, with qualified majority voting implemented for more labour and social issues. The Lisbon Treaty, coming into force on 1 December 2009, also gave the chance to take more decisions on the basis of a qualified majority. The Charter of Fundamental Rights of the EU, which came into force together with the new Treaty, made some of the main labour and social rights, including particular rights concerning industrial relations, common for EU member states.

Some peculiarities of labour and industrial relations policies in the EU-27 (which will be the EU-28 after 1 July 2013) have led to varying results for the Lisbon Strategy and could bring many variations concerning the impact of Europe 2020 on the national and European dimensions of industrial relations:

- there are many and various traditions of systems of industrial relations: inclusive; dualistic and market-based employment regimes; as well as Nordic, continental, liberal and southern patterns of industrial relations. However, there are also variations in eastern Europe. ${ }^{8}$ For instance, employment policies based on the Lisbon Strategy have been prepared and implemented in some regions and countries with tripartite agreements, while in others on the basis of autonomous agreements. The same could happen with new policies regarding employment and poverty

- the impact of the main pillars of European industrial relations is still low in the new EU member states, especially regarding main issues such as freedom of association for workers and employers; the co-ordination of collective bargaining; workplace information and consultation; and social pacts. In some countries, trade unions still have severe difficulties in establishing new structures and establishment relationships with employers. Information and consultation rights are still under-developed, especially in some countries such as Bulgaria, Poland and the Baltic states. Integration in the European social dialogue of the social partners in the new EU member states is not yet finished, especially at the sectoral level

- there is still no well-established and functioning common framework for labour and social standards at EU level. The continuing freedom of movement of workers still does not correspond to an appropriate legal framework

- the European social dialogue is challenged both by common EU objectives and national characteristics which continue to be strong. There are many difficulties in the process of reaching common agreements and then in implementing them

- data from some surveys shows that national associations of employers at sector and inter-sectoral levels have been weakened, and that the bargaining power of

7 European Commission (2008) Industrial relations in Europe 2008 Report of the European Commission (DG 'Employment, Social Affairs and Equal Opportunities', September, pp. 10-11.

8 ibid. 
trade unions has also slowed. ${ }^{9}$ There are trends towards the de-regulation of industrial relations and the de-centralisation of collective bargaining, often encompassing the use of open clauses and derogations in sector agreements. Most of these phenomena have been caused by the crisis, but some dimensions appeared even in the 1990s.

The results of the Lisbon Strategy show that the social partners were not always really involved in its implementation; there was on occasion more talk than action. ${ }^{10}$ There were not many successes in the integration of migrants and their involvement in national industrial relations systems; in the integration of young workers; in the prevention of discrimination; or in solving some of the issues related to lifelong learning. Some national trade unions still support views which are old, pre-globalisation and simply too closed. Employers tend generally to be much more open and pro-Europe, but many national associations of employers still support companies with short-term purposes. Governments sometimes use double standards - while some of their representatives often present anti-immigration speeches. Important examples of this are the recent speeches of some British politicians towards immigrants from Bulgaria and Romania while, in an earlier time, their positions towards immigrants from Poland and other east European countries served similarly. Also, the positions of the governments of the Netherlands and Finland and, recently, of the German government towards the accession of Bulgaria and Romania to the Schengen Area are evidence of double standards. On the other hand, many governments could not prevent illegal immigration, because it is difficult to observe the flows, or because it offers cheap labour for business.

It seems that Europe needs a new vision for industrial relations, which should be a response to the new challenges and which should be more European in orientation. The European social partners should also establish a social vision for Europe in the context of Europe 2020, including fair labour standards and also policies of social cohesion, in particular those which seek to narrow or eliminate the gaps between member states. Currently there are still many, and often strong, differences among member states because of the lower than average EU social standards existing in most new member states and because of the still-weak common labour and social standards which exist at EUlevel. Additionally, sometimes contradictions may appear between different member states, especially between old and new member states, in particular in cases of the transfer of enterprises/operations from one to another country and also in the case of contradictions caused by disputes regarding the social protection of migrant workers and 'social dumping' as regards wages and incomes.

National dimensions of industrial relations in the perspective of the Europe 2020 strategy - the case of Bulgaria

Bulgarian transformation of labour - main trends, challenges and perspectives

Bulgaria started to implement the Lisbon agenda before joining the European Union. Many difficulties resulted from privatisation and economic restructuring, but

9 ETUC (2010) Annual collective bargaining survey ETUC: Brussels.

10 Magnusson, L (2010) After Lisbon-Social Europe at the crossroads Working Paper 2010.01, ETUI: Brussels, p. 18. 
some results were reached in the 2003-2009 period. These were related mainly to the improvement in the business environment, as well as the liberalisation of the tax regimes (including the reduction of corporate tax and taxes on personal incomes to a level of $10 \%$ ) and the reduction in the level of insurance contributions. Additionally, some increase in employment rate from 2004-2008, and a reduction in the unemployment level to approximately $5 \%$ in September 2008, could be observed.

However, the results were not as successful regarding the improvement of administration and the abolition of the administrative barriers to business and regarding the establishment of the information society. The promotion of lifelong learning and the improvement of vocational training, and the implementation of the European social model and social inclusion, were also not particularly successful. The objectives concerning the employment rate were reached, mainly because of emigration and the growth in construction and estates, but, at the same time, it was mainly low- and medium-skilled jobs that were created. Between 2005 and 2008, there were even some labour shortages, especially in construction, some manufacturing sectors, IT and tourism, that appeared. Such deficits were caused mainly by emigration and the aging of population, but their appearance also indicated that there were problems within education and vocational training.

According to the opinion of the Bulgarian Economic and Social Council, which was discussed and passed in October 2010:

The twenty-year transition towards the market economy did not lead to the effective structural reforms in the economy and related fields. The perspective for long-term sustainable development is threatened by the inherited and newly-created fundamental structural problems of the economy. In Bulgaria, corporate governance is also still not sufficiently effective and the tax system, although one of the best for business in Europe, is still promoting short-term profit and speculation. Long-term business strategies are practically absent, with the exception of the strategies of some multinational subsidiaries and of some domestic investors, but too rarely among the latter group. At the same time, the influence of the crisis seems to be too long and painful. ${ }^{11}$

Subsequent to the onset of the crisis, there was a reduction of employment in Bulgaria - as of 2008, the level of employment (as a share of the whole population) was $50.8 \%$; in 2011 , it was $45.6 \%$; and, in the fourth quarter of 2012 , it was $47 \%{ }^{12}$ The trends in the level of unemployment correspond to the trends in employment - in 2008, the annual unemployment level was $5.6 \%$; in 2011, it was $11.2 \%$; and, for the fourth quarter of 2012, $12.4 \% .^{13}$

An appropriate Bulgarian response to the new challenges referred to in the Europe 2020 strategy means a continuation of economic restructuring; investment in transport and energy infrastructure; new changes in the business environment; the improvement of public administration and in the regulatory environment for business; and an increase

11 Economic and Social Council of Bulgaria (2010) Opinion on Strategic Priorities of the Bulgarian Economy within the Europe 2020 Strategy Sofia, September, p. 3. 
in the share of the carbon-free and low-carbon economy as well as in renewable energy resources.

The implementation of the Europe 2020 strategy in Bulgaria, and its impact on labour and labour relations, could also be challenged by several issues.

Environmentalism

The implementation of renewable energy resources, the promotion of low carbon sectors and company development and environmental protection as a whole are challenged by the 'strong traditions' of the old energy companies. The strongest resistance is expressed by energy business lobbies (in Bulgaria, there are several so-called lobbies for various types of energy - coal, gas and oil, and nuclear). Among the reasons which led to the decision taken by the government in April 2012 to stop the building of Belene, the new nuclear power station, could be mentioned not only the visible lack of potential efficiency, which was clear to many experts since the beginning of negotiations on the project in 2007, but also others like the probable pressure from the sidelines of some of the other non-nuclear lobbies.

However, the government was forced to organise in January 2013 a referendum on the establishment of new nuclear stations as a result of the initiative of the biggest opposition party, the socialists, which pushed for such a plebiscite following the government's decision to abandon Belene.

The referendum, whose main question was more general than the BSP wanted 'Should nuclear energy be developed further in Bulgaria by building a new nuclear power plant?' - since it did not focus precisely on the Belene plant, was practically boycotted by citizens. Only $22 \%$ voted and, although $60 \%$ of them voted 'yes', they represented about $12 \%$ of all those having the right to vote. The outcome was that parliament confirmed the decision not to establish Belene. Practically speaking, this decision does not preclude the possibility of the establishment of another nuclear plant (for example, the extension of the existing nuclear power facility at Kozloduy).

However, in February 2013a political crisis started in Bulgaria and this led to a decision being taken, after the resignation of the centre-right government and the refusal of all the parties to make any attempt to establish a new government in the framework of the existing National Assembly, to hold elections in May and then in July 2013. The crisis was mainly provoked by problems in the price of energy services - electricity and heating - and by mass demonstrations addressed initially towards monopoly companies in energy production and supply, and then towards the government and finally towards all politicians and the political system. Formally, the reasons for the demonstrations were the increase in electricity prices and, to some degree, of heating costs since the beginning of the year and dissatisfaction with the standard of living and with corruption among politicians. However, some business groups, including the energy lobbies, and especially those who are dissatisfied with the results of the referendum and with government decisions concerning the development of nuclear energy, also tried to use the dissatisfaction of the people to make political changes directed at the new government which could be more favourable to nuclear power.

At the same time, investments in some new energy companies, mainly in those using renewable energy resources (for example, wind) could also be resisted by farmers 
because such new companies could seek to use agricultural land. This could made a process of 'green' restructuring much more difficult than expected.

\section{Technological changes}

Radical changes in technology and in the promotion of particular innovations are also not easy with regard to their implementation. Research and development investment has been too low in the last 23 years, but the current budget deficits and budget restrictions caused by the influence of the crisis remain a barrier to the investment process in this area. At the same time, radical reforms in the R\&D sector, as well as in university education, have not yet been started and even the first steps which were made by the last government have encountered strong resistance. The average age of employees in universities and the sciences is too high; there are not many young candidates for academic jobs; and many high-level researchers, especially in mathematics and sciences, left the country in the 1990s.

Social policy reform

Bulgaria still has to continue with its reform of social security systems, in healthcare and social assistance and in education. However, such reforms would be painful as they have been prolonged and need to be continued under the new budget restrictions. Public expenditure on such sectors is suffering from the cuts, but it is not easy to implement reforms without money. Furthermore, the results are only deteriorating services, especially in healthcare and social assistance and in the support of old people, people with disabilities, children without parents and others. This could also reflect the reduction of employment in such areas, the worsening of services for small towns and villages and the transformation of the provision of social assistance to another mechanism, whose advantages are as yet unproven. The Bulgarian government and civil society are already severely challenged by the need to strike a better balance between financial sustainability and social cohesion.

\section{Industrial structure}

The industrial structure of Bulgaria is still out of proportion - the share of the nonformal economy, with jobs of low quality, is large and there are many low-value add and high energy-consuming industries and companies. The number of employees in the service sector is large, but it is mainly employees with low skill levels who are required. The country urgently needs to work out a new industrial strategy corresponding with the challenges of globalisation, the single European market and the Europe 2020 strategy, and establishing a friendly business environment for investment and job creation in preferred sectors.

These could be 'green' sectors or R\&D, but also sectors where the country has established, or could establish, competitive advantage. Some politicians, representatives of business and trade unions and academics think that tourism and so-called 'white-collar' services (spa and wellness tourism, healthcare, social assistance, childcare, education and training, sport and recreation) could be promoted as they could create new jobs. However, most views in this direction have been shared only in the context of non-formal discussions, or discussions inside non-government organisa- 
tions. Government representatives appear to share some such views (regarding healthcare and wellness and spa tourism), but they also expect that hi-tech businesses, machine-building, chemistry and pharmaceutics, and biotechnologies could be promoted.

\section{Human resources}

This problem area has neither been caused by the crisis nor has it been provoked by globalisation and integration in the common European market. The issues in the area of human resources has several main pillars: demography, especially the aging of the population; the emigration of young and skilled labour, which is still continuing; late reform of education and training, as well as of research and technological innovation; the freezing of innovation activity; the social exclusion of some groups; and the accumulation of the 'culture of poverty'.

Flexibility in work, education and training and work-life balance is still not in sufficient use in Bulgaria. Telework is at its beginning and is used mainly in the IT sector, while part-time work is used only in services. The part-time working of retired people, women with small children and students is not sufficiently encouraged or supported, while part-time study and distance learning are not promoted, with the exception of post-graduate qualifications and study for masters degrees.

\section{Labour costs and wages}

There is also a strong dissonance between the main positions of labour and capital on the market - labour costs and wages are the lowest in the EU-27. Between 2005 and 2008 , there were many companies offering comparatively high levels of wages, while some of the first steps towards competition were being made by companies active in the labour market and looking at individual bargaining over wages, but, after the beginning of the impact of the crisis, wages in many sectors have been frozen and such processes have been brought to a halt.

Furthermore, there are comparatively few differences between the levels of payment for low-skilled and skilled jobs.

\section{Equality}

Finally, new policies for equality need to be work out, including the promotion of the extension of opportunities for people in education and skills development, in career and creative activities, in entrepreneurship and in flexible and successful job changing.

\section{Industrial relations in Bulgaria after EU accession}

Industrial relations in Bulgaria has begun to recover since 1990, and the long process of adaptation to the requirements of a market economy was a precondition for the long process of establishing a European model of industrial relations. The current situation with regard to Bulgarian industrial relations and the social dialogue is as follows.

\section{Domestic weaknesses}

The influence of the European framework and the experience of member states has been positive, but the disadvantages caused by weak national traditions and poverty 
are still visible. The social partners from both sides need to make radical changes in their values, policies, structures and approaches. The competences of the representatives of the social partners still do not correspond to the challenges of the $21^{\text {st }}$ century (in terms of technological skills and competences, languages, communications skills, and others). Participation in the European social dialogue is still at the beginning and this is more visible among employers than among trade unions.

\section{Institutional structures}

The institutions of industrial relations and the social dialogue are well-established, especially the tripartite structures. There are already some traditions, but the influence of tripartite consultation is still enormously strong compared to bipartite consultation and collective bargaining. The reason for this is related to negotiations with the European Union starting comparatively late in Bulgaria, while in the 1990s the influence of the International Labour Organisation was dominant in the process of the recovery of industrial relations. In addition, the attitudes and expectations of most citizens as regards the state regarding social policies are still too strong.

The implementation of all EU directives concerning labour and social affairs has been discussed by the government, the social partners and other civil society organisations since the outset of negotiations to join the EU in 2000. Currently, the implementation of the acquis communautaire in labour law and social policy, as well as the preparation of new directives, are also discussed with the social partners.

\section{Sectoral social dialogue}

Bipartite partnership has, for a long time, been focused only on collective bargaining but, since 2001-02, further consultations at the national inter-sectoral level have been carried out and many painful issues, such as changes to the labour law, the level of insurance contributions and the indexation of wages in the business sectors, have appeared while the problems have begun to be resolved. The results of such consultations have been used by some governments in the last decade to implement some new changes in legislation and policies. At the same time, new requirements for minimum insurance levels have been implemented by the government which the social partners at sectoral level need to discuss and, eventually, agree on. Some of these issues include provisions in sectoral collective agreements, while some may seek separate agreements. Currently, bipartite consultations are occurring in many of the sectors.

At the end of 2010, the national inter-sectoral social partners agreed on two new issues - the labour relations of domestic workers and of teleworkers. National agreements with the government were signed which are intended to promote the employment of domestic workers and teleworkers and to ensure the maintenance of their rights.

Nevertheless, there continue to be many problems related to the social partners and to social dialogue at the national level, and in particular in some sectors. According to data from the survey carried out in 2010-2011 for the purposes of the CITUB project 
Security through law, flexibility via collective bargaining, ${ }^{14}$ as well as according to other similar surveys, there are several main trends:

- the structures of the social partners (the sectoral trade unions and associations of employers) have not changed since the early 1990s. The result has been many duplicated structures (mainly among employers), as well as many problems in the social dialogue and in industrial relations. In many cases, the structures do not correspond with the structures of the European partners of such institutions. However, changes in such structures could be made only if there is a will, expressed by organisations and their members, since membership is voluntary and decisions are taken by the governing bodies. Most of the representatives of the social partners prefer instead to preserve the status quo; the desire to discuss new issues is too weak and adaptation to the challenges is too slow. There is a resistance to possible changes and innovation, especially to those which are of an institutional/structural character. Trade union density is higher in manufacturing/mines/infrastructure services, as well as in sectors financed by the budget, than elsewhere. Trade union density is weakest in private services and in some of the new sectors of the economy. Density among employer associations is also higher in manufacturing/mines and lower in services, while in the public services/budget sector, employer associations in many cases exist only formally ${ }^{15}$

- collective bargaining exists in many sectors and, in some cases, at both sectoral and branch level depending on the industry in question. The other level is the company while, in some budget-financed sectors, there is also collective bargaining at the level of the municipality. The results of many surveys, including the one just mentioned, show that there too many differences in the scope and subject both of collective negotiations and agreements in the various sectors and at different levels, including as follows:

- in some sectors (mainly in manufacturing), the process of bargaining is already a tradition and there are some results; however, some of these have been 'frozen' as a result of the impact of the crisis. The most important purpose between 2008 and 2012 was to retain jobs, even when it was necessary to implement reductions in working time and wages

- $\quad$ some of the most important issues, like qualifications, lifelong learning, the improvement of skills, work flexibility, the arrangement of new regimes for working time and atypical employment have been put into the outlines of collective bargaining, but this happens more often at the company level and most often in some of the subsidiaries of multinationals

- 'green' restructuring and green jobs are still not within the focus of industrial relations and collective bargaining, again with the exception of some sub-

14 Supported by the operational programme 'Human Resources for Bulgaria (2007-2013)' and financed by the European Social Fund.

15 Ribarova, E, T. Mihailova, N. Nedev and E. Markova (2010) Main trends of the social dialogue and the collective bargaining in the sectors Working Paper (in Bulgarian) for the project Security through law, flexibility via collective bargaining Sofia: Confederation of Independent Trade Unions of Bulgaria. Operational programme 'Human Resources' of the National Strategic Framework for Bulgaria 2007-2013, pp. 104-112. 
sidiaries of multinational companies. At the same time, 'green companies' and renewable energy companies are new and, frequently, there are no trade unions or pattern of industrial relations there

- in the Bulgarian labour law, there has been provision for the extension of collective agreements since 2001, but this was implemented in practice for the first time in 2010. Many employers associations, individual employers and even some trade unions have resisted the extension of the provisions of collective agreements, which could make the implementation of some policies via collective bargaining more difficult than expected.

New forms of workplace representation

New forms of representation in the workplace, in particular systems for information and consultation, have been implemented in less than $25 \%$ of Bulgarian companies, where such forms are required by the law, even though all EU directives were transposed into the labour law in 2006. The situation is, again, better in subsidiaries of multinationals, where members of European Works Councils could also be elected.

At the same time, however, results from research studies carried out for the purposes of two projects - Improvement of the Process of Workplace Information and Consultation for better Employee and Workers Representation in Europe ${ }^{16}$ and The Role of Information and Consultation of Employees and Workers at National and European Levels for the Improvement of Competitiveness, Employment Growth and Better Implementation of the European Social Model ${ }^{17}$ - both financed from a European Commission budget line, do show some positive trends. In cases when information and consultation are used, the problems caused by the influence of the crisis are better resolved and many other issues are put under discussion, including skills and training, the redesign of jobs, flexible working time and productivity issues. ${ }^{18}$

\section{Corporate social responsibility}

Corporate social responsibility (CSR) is also a new phenomenon for Bulgaria. Currently, it is being implemented mainly by some big companies and, again, especially by multinationals. In some cases, CSR is also a subject for industrial relations - either via collective bargaining or via consultation. Nevertheless, concerning its still-separate implementation, CSR appears to be a mechanism which has an impact on education and skills levels in some regions and municipalities, as well as for job creation and poverty reduction, but only in particular cities and municipalities.

18 See Improvement of the Process of Workplace Information and Consultation for Better Employee and Workers' Representation in Europe (INFORMIA) Ref. No: Grant Agreement VS/ 2009/0486 of the European Commission, DG Employment, Social Affairs and Equal Opportunities, 2010. www.informiaproject.org; Information and Consultation in Europe. The Way Forward. European Comparative Report (INFORMIA-2) Ref. No: Grant Agreement VS/ 2011/0277 of the European Commission, DG Employment, Social Affairs and Equal Opportunities, 2012. www.informiaproject-2.org. 
Involvement in European social dialogue

One of the problems of significant importance in Bulgarian industrial relations is that the social partners are still not well involved in the European social dialogue. Trade unions (and also employers) are still not involved in the co-ordination of collective bargaining, due to the low level of wages and salaries in Bulgaria. The several national organisations, such as the two nationally-representative trade union confederations and some of the employer associations, have been members of European-level organisations for many years, but the national sectoral organisations still need greater efforts to be made as regards their EU integration. The sectoral trade unions are already members of the European sectoral federations, but their participation in the European social dialogue is still largely symbolic. Many sectoral employer associations are not even members of their European structures and their interests tend to be represented by their national inter-sectoral associations.

More active domestic participation

Finally, some of the objectives of the new Europe 2020 strategy require a more active participation on the part of the social partners as well as the restructuring of industrial relations in Bulgaria. It is important to translate the new issues into the language of industrial relations and to define the particular problems which exist at company and sectoral level. The other aim is to the involve social partners in the formulation of policies regarding the Europe 2020 objectives. However, this needs a long time and stronger efforts both by the social partners and by the government.

Main approaches of interaction between national and European industrial relations: the perspective of European and national frameworks of industrial relations

The far-reaching objectives of the new strategy require a better interaction between national and European industrial relations systems. There are several points which need to be borne in mind in such a process:

- first, European economic freedoms, competition, globalisation and social standards still do not correspond with the common European framework for labour market and social policies, and it is not clear whether such a framework could be established in the near future. Also in national systems of industrial relations, including the organising of workers and employees and employers, the co-ordination of collective bargaining, the implementation of fundamental rights at work and the introduction of information and consultation systems, there continue to be many differences resulting from national traditions and the lack of strong common rules for the EU. The influence of the EU in such areas, especially regarding the new member states, is still too weak ${ }^{19}$

- second, in the industrial relations development there are slow but strong dimensions of trans-nationalization and increasing of the importance of the European

19 European Commission (2008) Industrial relations in Europe 2008. Report of the European Commission Brussels: European Commission, DG Employment, Social Affairs and Equal Opportunities, September, p. 8. 
level. This includes industrial relations in the multi-national companies, transnational collective bargaining, information and consultation rights and European works councils, coordination of collective bargaining, European social dialogue. Such trends lead to some looses of importance of the national systems of industrial relations and challenge needs for more strong co-ordination among the social partners at the European and global level

- third, as a result of the 'green' revolution, there will be winners and losers probably among the various groups of workers and various regions/countries. It seems that some particular social policies and programmes should be prepared and implemented for the better identification of such groups and regions and for the finding of appropriate and timely solutions. Additionally, a new co-ordination between national and European levels of industrial relations and social dialogue needs to be founded

- fourth, the implementation of the policies of Europe 2020 is sure to lead to more and new forms of flexibility - increasing the importance of small- and microcompanies, flexible teams, flexible contracts, work functions and working time, and jobs and career change. This could create attitudes for the improvement of the standards of flexible jobs. Also, the improvement of labour protection under extended economic freedoms would be necessary, including protection of the right to work, lifelong learning, work-life balance and career development and mobility.

The impact and social dimensions of each new piece of legislation, both at national and at European level, should be analysed better and assessed in advance, while the opinions of the social partners and civil society should be taken into account, including the European Economic and Social Council and national economic and social councils or similar bodies. Member states declare, by signing the Treaty of Lisbon, that they accept freedom of movement and freedom of competition, but the Charter of Fundamental Rights is the instrument by which the European Union recognises the supremacy of fundamental rights and their central place in the structure and mission of the EU.

The main objective of a socially-stronger Europe should be the development of adequate mechanisms for overcoming the negative social consequences of free mobility. These are the acquis communautaire - a set of legal norms which have been developed precisely with this aim in mind - to add a little social harmonisation to the market. Some of these norms (such as the directives on atypical employment or against gender discrimination) address the new social risks of the post-industrial society.

At the same time, however, circumstances demand greater action to be undertaken in the context of the present situation (especially taking the crisis into consideration):

- the creation and reinforcement of a common layer of labour law guarantees, especially with respect to non-standard employment

- agreement on common definitions and criteria regarding areas such as social security, services of general interest, etc., which are extremely sensitive to increased mobility - finding the balance between eliminating local immunities and protectionism and retaining legitimate differences between member states

- establishment of common rules for minimum wages, on the one hand, and launching an initiative for a common guarantee of minimum income, on the other, in order to protect the most vulnerable groups. During the preparation of the Charter of 
Fundamental Rights in 2000, the question of minimum income was put into discussion but no agreement was reached. Currently, the issues of a common minimum wage and common minimum income have already become more important

- actualisation and co-ordination of the social security regime for migrant workers

- measures to avoid social dumping ${ }^{20}$

- also, some of the fundamental rights at work, such as rights for organising, for collective bargaining and strikes, and for workplace information and consultation, should be improved in the common European legal framework and even steps taken towards their trans-nationalisation. Suggestions for the trans-nationalisation of such rights were put into the discussion by trade union representatives during the preparation of the Charter of Fundamental Rights but, again, no agreements were reached.

For Bulgaria, there are also some particular dimensions:

- Bulgarian society in general is not familiar with European norms, and it is hardly surprising therefore that most citizens are not familiar with the Charter of Fundamental Rights of the European Union, including the labour and social rights stipulated therein. Moreover, there is a tendency for individuals to remain aloof and expect protection from an institution, non-governmental organisations, trade unions, etc. without taking any action themselves

- the expansion of the open market in the EU is not being accompanied by the creation of the necessary new social norms both at the EU and the national level. This explains part of the difficulties related to the practical achievement of social protection in the context of the open internal market, free competition and the free movement of goods, services, capital and people - which are characteristic of relatively new and comparatively poor member states - irrespective of the legal system being fully in line with EU requirements concerning labour law and social norms

- what is particular about Bulgaria is that it is a country with the lowest cost of labour in the EU-27, which is a prerequisite for attracting capital investment, outsourced enterprises and operations from wealthier member states. These processes, however, are not so frequent in Bulgaria at the moment due to complicated administrative procedures, a relatively small market, the competition of neighbouring countries and the continuous emigration of the workforce, especially of skilled workers and specialists, as well as the impact of the global financial crisis. This does not mean that there is no potential for an increase in foreign investment in Bulgaria, especially if the cost of labour remains low. This can have a positive effect, such as the creation of new jobs, but it can also lead to some controversies between Bulgarian government and civil society and the governments and civil societies of EU member states which are exporting capital. This is already visible in relations between national trade unions from western and eastern Europe. This is why it is worth reconsidering the policies of attracting investment and the coun-

20 Economic and Social Council of Bulgaria (2010) Opinion on the Social Dimensions of the Treaty of Lisbon Sofia, November, p. 29. 
try's attractiveness also with respect to the social objectives of the Treaty of Lisbon, including the attraction of investment in new enterprises, green investment, etc.

- for the time being, Bulgaria is predominantly exporting its workforce to other member states. To a certain extent, this relieved the national labour market, especially in the period 2003-2008. At the same time, it has caused other problems. The first is related to the social protection of migrants, including self-employed migrants, because many of these are not employed in accordance with the respective working conditions and national standards of host countries. The second problem is related to 'red lines', i.e. safety clauses, and the possible imposition of more such restrictions especially with respect to the free movement of people and the social protection of migrants. In this context, it is necessary to reconsider Bulgaria's immigration policy. The country's policy in this direction pays more attention to the provision of a skilled workforce from abroad than it does to the protection of working migrants

- despite Bulgaria now having been a member of the EU for more than six years, it still does not participate in the most suitable way in the formulation of common EU policies and the adoption of different decisions. Additionally, it still does not show any clear national positions or demonstrate any attempt to defend its interests. This applies also to policies in the field of the labour market and the social sphere. The main reasons for this are related to Bulgaria and Romania only having become member states in 2007 but also to the problems in the implementation of the programmes and projects financed by the EU's structural and cohesion funds which still exist in both countries but more visibly so in Bulgaria. Nevertheless, it is sure that the increasing activity of the government and non-governmental representatives at the EU level and the improvement of the quality of their opinions, especially in regards to the labour market, labour standards and social policy, could help the country improve its prestige within the EU and within Europe.

\section{Conclusions}

The more and the better the level of integration and co-ordination between the national and the international/European levels of industrial relations, social dialogue and legal frameworks, the better the available social protection of those rejected during restructuring and the level of advantage regarding education, job creation and poverty reduction. At the same time, the national focus is too strong and every step towards trans-nationalisation, both of the legal framework for labour and social policy and of industrial relations, will be challenged by resistance as well as by fear. 


\section{References}

'Big business demands accountability on EU 2020' www.euractiv.com.

Communication from the Commission to the European Parliament, the Council, the European Economic and Social Committee and the Committee of the Regions (2010) Europe 2020. A European strategy for smart, sustainable and inclusive growth European Commission: Brussels, February.

Communication from the Commission to the European Parliament, the Council, the European Economic and Social Committee and the Committee of the Regions (2010) Towards a single market act. For a highly competitive social market economy European Commission: Brussels 11 November.

Communication from the Commission to the European Parliament, the Council, the European Economic and Social Committee and the Committee of the Regions (2011) Annual growth survey: advancing the EU comprehensive response to the crisis European Commission: Brussels, 12 January.

Daskalova, N (E.) (2009) Multinational companies - 2008. European dimensions of industrial relations (in Bulgarian) Sofia: Institute for Social and Trade Union Research / Friedrich-Ebert-Stiftung.

Economic and Social Council of Bulgaria (2010) Opinion on the Social Dimensions of the Treaty of Lisbon Sofia, November.

Economic and Social Council of Bulgaria (2010) Opinion on the Strategic Priorities of the Bulgarian Economy within the Europe 2020 Strategy Sofia, September.

ETUC (2010) Annual collective bargaining survey ETUC: Brussels.

ETUC (2010) The European 2020 strategy: Facing the crisis: is European employment policy up to the challenge? ETUC: Madrid, March.

ETUC, BUSINESSEUROPE, CEEP, UEAPME (2010) Joint Statement on the Europe 2020 Strategy 4 June.

ETUI (2012) Benchmarking Working Europe 2012 ETUI: Brussels.

'EU at risk if Europe 2020 fails to deliver' www.euroactiv.com 9 February 2011.

European Centre for the Development of Vocational Training (2010) Skills for green jobs European synthesis report, in conjunction with the International Labour Office, Luxemburg: Publications Office of the European Union.

European Commission (2008) Industrial relations in Europe 2008. Report of the European Commission DG Employment, Social Affairs and Equal Opportunities, Brussels, September.

European Commission (2010) Industrial relations in Europe 2010 Report of the European Commission DG Employment, Social Affairs and Inclusion, Brussels, October.

European Commission (2010) The Lisbon Strategy http://ec.europa.eu/growthandjobs/ index_en.htm 
Fayole, J (2011) New skills for new jobs - the scope for trade union intervention and sectoral dialogue ETUI Policy Brief on Social Policy, Issue 1.

Improvement of the Process of Workplace Information and Consultation for Better Employee and Workers' Representation in Europe (INFORMIA) Ref. No: Grant Agreement VS/2009/0486 of the European Commission, DG Employment, Social Affairs and Equal Opportunities, 2010. www.informiaproject.org.

Information and Consultation in Europe. The Way Forward. European Comparative Report (INFORMIA-2) Ref. No: Grant Agreement VS/2011/0277 of the European Commission, DG Employment, Social Affairs and Equal Opportunities, 2012. www.informiaproject-2.org.

'Labour markets continue to evolve through crisis' www.euractiv.com February.

Magnusson, L (2010) After Lisbon - Social Europe at the crossroads ETUI Working Paper, ETUI, Brussels.

'Merkel criticizes Europe 2020 strategy' www.euractiv.com March 2010

National Statistical Institute (2013) Data for the labour market www.nsi.bg.

Pochet, P (2010) What is wrong with Europe 2020? ETUI Policy Brief on Social Policy, Issue 2.

Ribarova, E, T. Mihailova, N. Nedev and E. Markova (2010) Main trends of the social dialogue and the collective bargaining in the sectors Working Paper (in Bulgarian) for the project Security through law, flexibility via collective bargaining Sofia: Confederation of Independent Trade Unions of Bulgaria. Operational programme 'Human Resources' of the National Strategic Framework for Bulgaria 2007-2013, supported by the European Social Fund, pp. 104-112.

Schoeman, I (2010) The Lisbon Treaty - the more social Europe at last ETUI Policy Brief on Social Policy, Issue 1.

'Seven steps to deliver on European strategies for growth and jobs' www.euractiv.com February 2010.

Sperotti, F (2010) Europe 2020: a strategy for XXI century www.adapt.it 13 October.

Tilkidjiev, N and L. Dimova (2010) Welfare and trust: Bulgaria in Europe. Comparative analysis based on the European social survey 2006/2009 (in Bulgarian), Sofia: East-West. 